\title{
Evaluation of a Climate change-Adaptive, Eco-Friendly Agronomic Package for Potato (Solanum tuberosum L.) Cultivation in the Farmer Fields of the Jaffna District of Sri Lanka
}

\author{
R. Eeswaran ${ }^{*}$, W.A.J.M. De $\operatorname{Costa}^{1}$, D.M. De $\operatorname{Costa}^{2}$, W.S. Dandeniya ${ }^{3}$ \\ S. Sivakumar ${ }^{4}$ and L.D.B. Suriyagoda ${ }^{1}$ \\ Postgraduate Institute of Agriculture \\ University of Peradeniya \\ Sri Lanka
}

\begin{abstract}
Potato is one of the key annual upland cash crops cultivated in the Jaffna District of Sri Lanka. However, potato farmers are challenged by climate extremes, increasing pest/disease loads and excessive use of agro-chemicals all of which are expected to increase in the future. To address these critical issues, a package of climate changeadaptive and eco-friendly agronomic practices that included mulching to conserve soil moisture, integrated pest management for crop protection and site-specific fertilizer management for efficient crop-soil nutrient management (adaptation package) was formulated and tested on potato (Solanum tuberosum L.) crops in seven farmer fields in Jaffna. The experiment was conducted in the major rainy season (Maha) of 2013/2014 and $2014 / 2015$ and consisted of two treatments as Adaptation package $\left(T_{1}\right)$ and Existing practice $\left(T_{2}\right)$, which is the current farmers' practices characterized with heavy reliance on chemical control of pests and diseases and application of inorganic fertilizers subsequent to decisions of farmer. The results revealed significant $(p<0.05)$ benefits of the above climate changeadaptive, eco-friendly agronomic package in terms of growth, yield, economic profit and environmental health of potato cultivation. Benefits of the adaptation package were greater in the drier and warmer 2014/15 Maha season, thus demonstrating its climate resilience. Therefore, the tested adaptation package can be recommended for adoption by the farmers to improve the yield of potato while promoting lower water and agro-chemical use thereby having increased resilience to climate change and improved environmental sustainability especially in the dry regions where potato is cultivated.
\end{abstract}

Keywords: Adaptation package, integrated pest management, mulching, potato, site-specific fertilizer management

\section{INTRODUCTION}

Potato is one of the important upland annual crops in Sri Lanka, which is cultivated in an annual extent of $c a .5000$ ha with an average yield of $15 \mathrm{t} \mathrm{ha}^{-1}$ (DOA, 2014). The crop is commonly cultivated in Nuwara-eliya, Badulla, Kalpitiya and Jaffna. The average yield is far below the potential yield as the crop is heavily affected by pest and disease attacks and

\footnotetext{
Department of Crop Science, Faculty of Agriculture, University of Peradeniya, Sri Lanka

Department of Agricultural Biology, Faculty of Agriculture, University of Peradeniya, Sri Lanka

Department of Soil Science, Faculty of Agriculture, University of Peradeniya, Sri Lanka

4 Provincial Department of Agriculture, Northern Province, Jaffna, Sri Lanka

Corresponding author: eeswaranr@gmail.com
} 
improper soil fertility management (Abhayapala et al., 2014). Excessive use of synthetic chemicals and unbalanced use of inorganic fertilizers are the common practices performed by all the potato growers to maintain the productivity of their lands and profits. Moreover, supplementary irrigation has become more important especially in the dry zone even in the rainy seasons.

Increasing ambient temperatures, altered rainfall patterns, declining soil fertility and changed pest/ disease dynamics are key aspects of climate change that are relevant to crop production (Rosenzweig et al., 2008; Gregory et al., 2009; St. Clair and Lynch, 2010). These impacts have high potential to accelerate the existing climatic constraints of potato crop production mainly in the vulnerable dry regions of the country. According to Punyawardena et al. (2013), the Northern Province which includes Jaffna is one of the extreme representatives of the low country dry zone of Sri Lanka, already experiencing above average ambient temperatures and below average precipitations. Moreover, its groundwater-based cropping systems with high exploitation of irrigation water from shallow aquifers makes farming activities vulnerable to climate change (Sood et al., 2015). Thus formulation, testing and adoption of climate change-adaptive options to enhance the adaptive capacity of agriculture based livelihoods in the most vulnerable areas is an urgent requirement (Howden et al., 2007; Meinke et al., 2009 and Lobell, 2014). As indiscriminate use of agrochemicals has already caused severe environmental hazards in the Jaffna Peninsula, increased emphasis is being given to eco-friendly approaches of crop protection and soil nutrient management (Vithanage et al., 2014).

Hence, the objective of the present work was to test a package of climate change-adaptive and eco-friendly practices for potato which comprised of mulching for soil moisture conservation, integrated pest management (IPM) for environment-friendly crop protection and site-specific fertilizer management (SSFM) for efficient crop-soil nutrient management in the farmer fields of Jaffna District to study its performances on growth, yield, economy and environmental friendliness in comparison to the existing farmers' practice. This package was formulated for upland cropping systems through a comprehensive multi-locational onstation field study (Abhayapala et al., 2014; Chathurika et al., 2014; Malaviarachchi et al., 2014 and Prasannath et al., 2014) for five candidate upland crops.

\section{MATERIALS AND METHODS}

\section{Site description and growing season}

The study was conducted as an adaptive research experiment during the major rainy season (Maha) of 2013/2014 (season 1) and 2014/2015 (season 2) in the farmer fields located in the Nilavarai village of Kopai Divisional Secretariat and Puthur Agriculture Instructor's Division within the mean latitude-longitude coordinates of $9^{\circ} 45.86^{\prime} \mathrm{N}$ and $80^{\circ} 5.78^{\prime} \mathrm{E}$ and located at 17-26 m above mean sea level.

\section{Selection of farmers for adaptive research}

Farmers were selected through a structured questionnaire survey along with the guidance of the extension officers of the Department of Agriculture. The questionnaire was aimed to collect baseline information about the existing farming practices ( 78 farmers from the Northern Province) and willingness of the farmers to test the new practices. A Total of seven 
farmers who were selected for this adaptive research participated in the experiment in both seasons.

\section{Experimental design and treatments}

The experiment was consisted of two treatments as 'Adaptation package' $\left(\mathrm{T}_{1}\right)$ where a combination of climate change-adaptive, eco-friendly agronomic practices were practiced and 'Existing practice' $\left(\mathrm{T}_{2}\right)$ which was the current farmer practices characterized with heavy reliance on chemical control of pests and diseases and application of inorganic fertilizers subsequent to decisions of farmer. The two treatments were imposed in a Randomized Complete Block Design where the selected farmers were considered as blocks to eliminate the farmer to farmer variability. The dimension of each individual plot was $5 \mathrm{~m} \times 5 \mathrm{~m}$.

\section{Crop establishment and management}

Potato cv. Red Lasoda seed tubers were directly established as a single tuber per hill at a spacing of $60 \mathrm{~cm} \times 45 \mathrm{~cm}$. Mulching, IPM and SSFM were practiced in the adaptation package $\left(\mathrm{T}_{1}\right)$ for soil moisture conservation, crop protection and crop-soil nutrient management respectively. Other crop management practices except the above adaptation practices for the $T_{1}$ were followed as recommended by the Department of Agriculture. The existing practice $\left(\mathrm{T}_{2}\right)$ was completely comprised the current farmer practices. Both treatments were planted at the same time.

\section{Components of the adaptation package $\left(T_{1}\right)$}

\section{Mulching and water conservation}

Neem (Azadirachta indica) leaves were applied as a mulch at the rate of approximately $8 \mathrm{t}$ $\mathrm{ha}^{-1}$ (fresh weight basis) at three to four weeks after planting (after the inter-cultivation). Farmers were advised to reduce the amount of irrigation as the mulch was estimated to conserve $30-40 \%$ of soil water in comparison to a non-mulched field (Kumar and Lal, 2012).

\section{Integrated pest management (IPM)}

IPM was included with the following list of crop protection components (Table 1). 
Table 1. Description of the integrated pest management (IPM) components included in the adaptation package treatment

\begin{tabular}{|c|c|c|}
\hline IPM component & Details of the application & Time of application \\
\hline $\begin{array}{l}\text { Establishment of a } \\
\text { barrier }\end{array}$ & $\begin{array}{l}\text { Thick white colour polythene } \\
\text { sheet at the height of } 1.5 \mathrm{~m} \text { around } \\
\text { the potato plots }\end{array}$ & $\begin{array}{l}\text { Before the establishment of } \\
\text { potato crops }\end{array}$ \\
\hline Soil drenching & $\begin{array}{l}\text { Application of bleaching powder } \\
{\left[\mathrm{Ca}\left(\mathrm{OCl}_{2}\right) . \mathrm{CaCl}_{2} \cdot \mathrm{H}_{2} \mathrm{O} . \mathrm{Ca}(\mathrm{OH})_{2}\right]} \\
\text { solution of } 2 \%(\mathrm{w} / \mathrm{v}) \text { solution, at } \\
\text { the rate of } 50 \mathrm{ml} \text { per planting hole }\end{array}$ & $\begin{array}{l}\text { About } 7 \text { to } 10 \text { days after } \\
\text { germination }\end{array}$ \\
\hline $\begin{array}{l}\text { Application } \\
\text { Salicylic acid }\end{array}$ & $\begin{array}{l}\text { Spraying to the canopy at the } \\
\text { concentration of } 400 \mu \mathrm{M}\end{array}$ & $\begin{array}{l}\text { After canopy establishment } \\
\text { at monthly intervals }\end{array}$ \\
\hline $\begin{array}{l}\text { Hanging of sticky } \\
\text { traps }\end{array}$ & $\begin{array}{l}\text { Made out of yellow colour bristle } \\
\text { board and transparent sheets } \\
\text { (approximately 7" } \times 7 " \text { ) and } \\
\text { covered with Vaseline and placed } \\
\text { above the canopy level at the } \\
\text { density of four sheets per plot. }\end{array}$ & $\begin{array}{l}\text { After establishment of the } \\
\text { crops in the field, traps } \\
\text { were hanged at canopy } \\
\text { level and the trap height } \\
\text { was raised as the crops } \\
\text { grew }\end{array}$ \\
\hline $\begin{array}{l}\text { Application of baking } \\
\text { soda }\left(\mathrm{NaHCO}_{3}\right) \\
\text { solution to the foliage }\end{array}$ & $\begin{array}{l}2 \%(\mathrm{w} / \mathrm{v}) \text { solution with few drops } \\
\text { of Teepol }{ }^{\circledR} \text { (as surfactant) was } \\
\text { sprayed to the crop canopy }\end{array}$ & $\begin{array}{l}\text { After canopy establishment } \\
\text { at two week intervals }\end{array}$ \\
\hline $\begin{array}{l}\text { Application of a talc } \\
\text { based bio-pesticide }\end{array}$ & $\begin{array}{l}\text { Spraying } 10^{6} \mathrm{cfu} / \mathrm{ml} \text { of bio- } \\
\text { pesticide (Bacillus megaterium) to } \\
\text { cover the foliage }\end{array}$ & $\begin{array}{l}\text { After canopy establishment } \\
\text { at two week intervals } \\
\text { alternatively with baking } \\
\text { soda }\end{array}$ \\
\hline $\begin{array}{l}\text { Application of neem } \\
\text { seed kernel extract } \\
\text { (NSKE) }\end{array}$ & $\begin{array}{l}5 \%(\mathrm{w} / \mathrm{v}) \text { NSKE was sprayed to } \\
\text { the crop canopy }\end{array}$ & $\begin{array}{l}\text { After canopy } \\
\text { establishment, at once per } \\
\text { cropping season during the } \\
\text { crop developmental stage }\end{array}$ \\
\hline $\begin{array}{l}\text { Manual removal of } \\
\text { infested plant parts, } \\
\text { with intact eggs and } \\
\text { pupae }\end{array}$ & $\begin{array}{l}\text { As soon as noticed, they were } \\
\text { removed manually }\end{array}$ & $\begin{array}{l}\text { During frequent } \\
\text { observations of the crops }\end{array}$ \\
\hline $\begin{array}{l}\text { Maintaining naturally } \\
\text { growing flowering } \\
\text { plants in order to } \\
\text { promote natural } \\
\text { enemies }\end{array}$ & $\begin{array}{l}\text { Naturally growing flowering } \\
\text { plants were maintained while any } \\
\text { over growing weeds that disturb } \\
\text { the crops were removed }\end{array}$ & $\begin{array}{l}\text { After establishment } \\
\text { main crops in the field }\end{array}$ \\
\hline
\end{tabular}

\section{Site-specific fertilizer management (SSFM)}

An analytical sample was prepared by combining the soil samples collected from all farmer fields (one sample per farm) taken at the depth of $c a .0-15 \mathrm{~cm}$ as the collected samples did not show significant differences on their basic soil properties $(\mathrm{pH}$, electrical conductivity, and organic matter content). The composite sample was analyzed for both macro and micro nutrients before the establishment of crops in the fields. Soil pH was determined in a 1:2.5 soil: distilled water suspension. Electrical conductivity was determined in a soil suspension prepared by $10 \mathrm{~g}$ soil with $25 \mathrm{ml}$ of distilled water (1:2.5 soil: water) and measured by a 
digital Electrical Conductivity meter. Soil organic matter content was measured by digestion with an acid dichromate solution and titrating with Ferrous Ammonium Sulphate according to the modified Walkley and Black method (Nelson and Sommer, 1996).

Available nutrients were extracted by a three step extraction procedure described by Portch and Hunter (2002) and analyzed accordingly. The amount of each nutrient to be added to reach the optimum nutrient level was calculated (Portch and Hunter, 2002). Site specific fertilizer recommendation was formulated based on the results of the above procedure as, Department of Agriculture recommendation for N, P and K with addition of Sulphur (Table 2). Table 3 indicates the fertilizer management under the existing farmer practice $\left(T_{2}\right)$.

Table 2. Formulated site-specific fertilizer mixture (SSFM) included in the adaptation package

\begin{tabular}{|c|c|c|c|c|}
\hline SSFM $\left(\mathrm{kg} \mathrm{ha}^{-1}\right)$ & Urea & T.S.P & M.O.P & Sulphur \\
\hline Basal dressing & 55 & 270 & 125 & 5 \\
\hline $1^{\text {st }}$ Top dressing (2WAP) & 110 & & & \\
\hline $2^{\text {nd }}$ Top dressing ( 3 to 4 WAP) & 165 & & 125 & \\
\hline
\end{tabular}

WAP: weeks after planting

Table 3. An approximate amount and type of fertilizer applied by farmers under the existing practice

\begin{tabular}{llll}
\hline Fertilizer applied $\left(\mathbf{k g ~ h a}^{-\mathbf{1}}\right)$ & $\begin{array}{l}\text { Potato } \\
\text { basal } \\
\text { mixture }\end{array}$ & $\begin{array}{l}\text { Ammonium } \\
\text { sulphate }\end{array}$ & $\begin{array}{l}\text { Potato } \\
\text { top } \\
\text { mixture }\end{array}$ \\
\hline $\begin{array}{l}\text { Basal dressing } \\
\text { Top dressing (3 to 4 WAP) }\end{array}$ & 500 & 280 & - \\
\hline WAP: weeks after planting & - & - & 500 \\
\hline
\end{tabular}

\section{Measurements and Data collection}

Vegetative parameters such as leaf area and total crop biomass were measured both at $50 \%$ flowering and harvesting stages through destructive sampling. Fresh tuber yield was measured at the time of harvesting from a pre-determined central area $\left(2.7 \mathrm{~m}^{2}\right)$ of the plot of potato crops. Major pest/disease incidences were continuously monitored by their respective field symptoms in each treatment plot at the initial stage (3-5 weeks), crop development stage (5-7 weeks), mid season stage (7-9 weeks) and late season stages (9-11 weeks).

Any changes in soil nutrients during the cropping season under the two experimental treatments were determined by analysing soil samples from each farmer fields at the beginning and end of the season. $\mathrm{N}, \mathrm{P}, \mathrm{K}, \mathrm{pH}, \mathrm{EC}$ and organic matter content were measured for this purpose by adopting the methods described in section SSFM, with the exception that the Kjeldahl method was used to determine total soil nitrogen (Bremner, 1960). An approximate cost and benefit comparison was done under the two crop management practices by accounting only for the specific practices involved in this study as farmers failed to keep records of expenses for operations such as land preparation, inter-cultivation, irrigation etc. The environmental impact of crop protection measures used in the two crop management systems was calculated by using the field environmental impact quotient (FEIQ) described by Kovach et al. (1992). The overall average of agro-chemicals used by 
the farmers was considered to calculate the FEIQ of the existing practice while FEIQ values of bleaching powder (Sodium hypochlorite) and neem seed extract (Azadirachtin) were used under the adaptation package.

\section{Data analysis}

The parametric data were analyzed by analysis of variance (ANOVA) procedure for the Randomized Complete Block Design (Steel et al., 1997). Descriptive statistics were used in comparisons of cost-benefits and FEIQ.

\section{RESULTS AND DISCUSSION}

\section{Meteorological observations during the research}

The potato growing season in the Jaffna District is the majour rainy season (Maha) in Sri Lanka. The Figure 1 shows the variation of daily rainfall, daily maximum temperature and minimum temperature during the two seasons from planting to harvest.
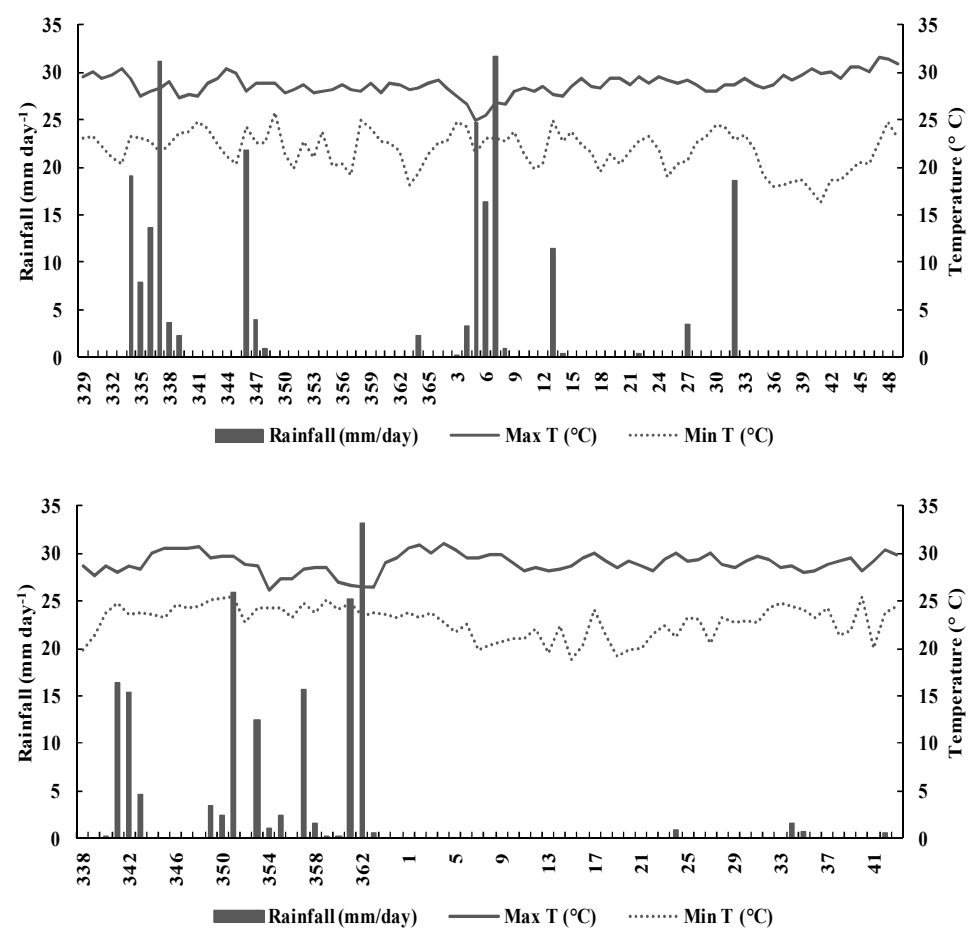

Fig 1. Daily values of rainfall, maximum temperature and minimum temperature during (a) maha 2013/2014 (Season 1) and (b) maha 2014/2015 (Season 2). Source: Department of Meteorology, Jaffna Office, Thirunelvely, Sri Lanka. 
The total rainfall from the time of planting to harvest during Season 1 was $217.9 \mathrm{~mm}$ and the mean maximum and minimum temperatures were $28.7^{\circ} \mathrm{C}$ and $21.8^{\circ} \mathrm{C}$ respectively while during Season 2, the total rainfall was $164.5 \mathrm{~mm}$ and the mean maximum and minimum temperatures were $29^{\circ} \mathrm{C}$ and $22.8^{\circ} \mathrm{C}$. These values were in the normal range of rainfall and temperature for these periods of the year in the low country dry zone (DOA, 2014).

\section{Vegetative parameters of crop growth}
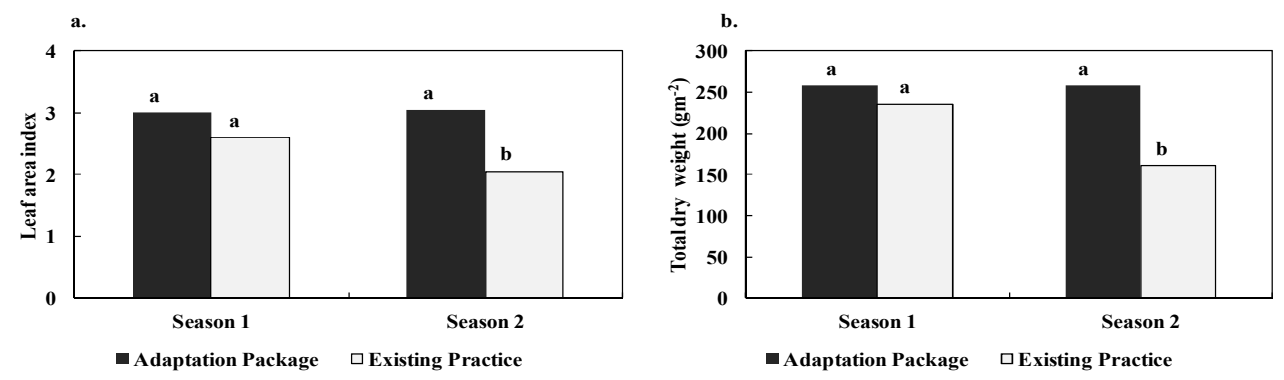

Fig 2. Vegetative growth parameters of potato (a: green leaf area index; b: total dry weight) at $50 \%$ flowering stage under the two crop management systems. Note: Means with the same letter within a given season are not significantly different at $p=0.05$.

As shown in Figures 2 and 3, during Season 1, statistical significance was not observed for green leaf area index and total dry weight at both growth stages under the two crop management systems. However, the adaptation package significantly $(p<0.05)$ improved leaf area index and total dry weight over the existing practice during Season 2 as mulching, IPM and SSFM enhanced the growth of potato when farmers increasingly adapted the package (Kumar and Lal, 2012; Chathurika et al., 2014 and Prasannath et al., 2014).
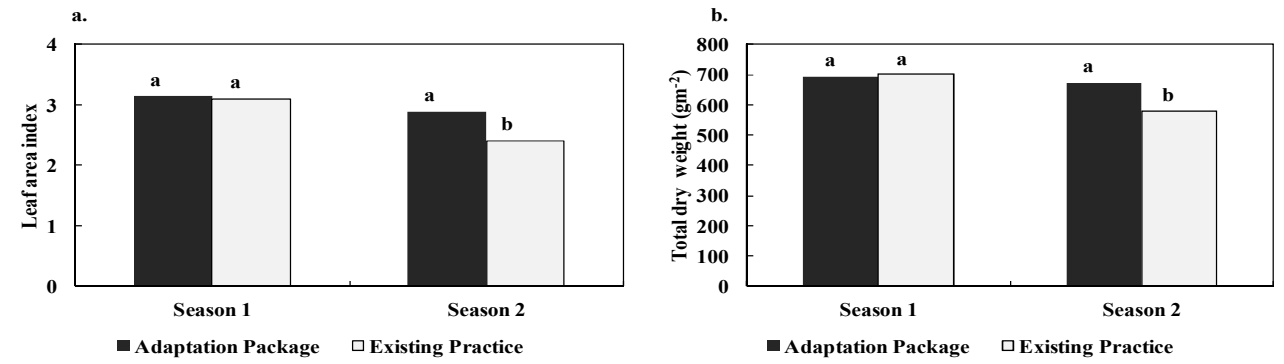

Fig 3. Vegetative growth parameters of potato (a: green leaf area index; b: total dry weight) at harvesting stage under the two crop management systems. Note: Means with the same letter within a given season are not significantly different at $p=0.05$.

\section{Pest and disease incidence}

Significant pest or disease problems were not encountered by potato crops growing under both crop management practices in the two seasons. Interestingly, crops in the nearby farmer fields which were planted with the same variety but one month later showed heavy 
infestation with bacterial wilt resulting in yields less than $10 \mathrm{tha}^{-1}$. Therefore, it was clear that the pathogen of bacterial wilt (Ralstonia solanacearum) was present in the soil under the prevailing environmental conditions and that the particular potato variety used was susceptible to the disease. However, the lower bacterial wilt incidence in the plots of the present study could be due to the influence of IPM practices which included soil drenching with bleaching powder and the application of a mulch. Incidence of the disease in the fields nearby showed that the soil was infested with the bacterium at the beginning of the season. However, the treatment of our plots with bleaching powder could have reduced the initial inoculum density, thus preventing incidence of the disease. Furthermore, mulching could have contributed to the reduction of inoculum density through exudates and strengthened the vigour of the plant to increase its resistance against pathogen infection (Abawi and Widmer, 2000).

Therefore, adoption of this IPM package could have reduced substantially the chemical costs of crop protection while being considerably more effective and environmentally-friendly. It is also possible that the earlier planting of crops of the present study enabled them to avoid the environmental conditions which were favourable for infestation with the bacterial wilt pathogen. Even though, the late blight disease is the major potato disease in the upcountry wet zone it was not observed in Jaffna because the optimum temperature for spore formation of Phytopthera infestans ranges from $18-20{ }^{\circ} \mathrm{C}$ (Schumann and Arcy, 2000). However, meteorological records showed that the environmental temperatures in Jaffna always remained supra-optimal to spore formation of the above pathogen (Figure 1).

\section{Fresh tuber yield}

During Season 1, fresh tuber yield of the two crop management systems were not significantly $(p=0.05)$ different. However, during Season 2, crops under the adaptation package had significantly $(p<0.05)$ greater fresh tuber yield than in crops under the existing farmer practices (Table 4).

Accordingly, during the first season, the adaptation package performed equally with the existing practice in relation to growth and yield. However, during the second season, the adaptation package significantly improved the growth and yield of potato than the existing chemical intensive crop management of farmers. The better performance of the adaptation package during the second season may be due to the better adoption of the introduced practices of the adaptation package (e.g. IPM, SSFM and mulching) by farmers. Adoption is always time consuming as framers need to overcome several barriers in the adaptation measures (Antwi-Agyei et al., 2015).

Moreover, the rainfall was fairly high and evenly distributed throughout Season 1. In such a situation, water availability would not have been a limiting factor, thus negating any advantage of soil moisture conservation through mulching. In contrast, during Season 2, rainfall was lower and was confined to the first three weeks of the crop (Fig. 1). Hence, mulching benefited in conserving soil moisture for crops under the adaptation package. This observation also demonstrated that the adaptation package performed better than the existing farmer practice, especially during unfavourable seasons such as those having lower water availability. As it is highly likely that water availability could decrease in a future climate in Sri Lanka (De Costa, 2008), the adaptation package tested in the present study has demonstrated its resilience to climate change impacts. 
Table 4. Fresh tuber yield of potato $\left(\mathrm{t} \mathrm{ha}^{-1}\right)$ at the physiological maturity under the two crop management systems

\begin{tabular}{lll}
\hline Treatment & \multicolumn{1}{c}{ Season 1 } & \multicolumn{1}{c}{ Season 2 } \\
\hline Adaptation package & $27.90 \pm 2.8 \mathrm{a}$ & $26.66 \pm 2.7 \mathrm{a}$ \\
Existing practice & $28.50 \pm 1.6 \mathrm{a}$ & $22.42 \pm 1.5 \mathrm{~b}$ \\
\hline
\end{tabular}

Note: Mean values given with their associated standard errors. Means with the same letter within a given season are not significantly different at $p=0.05$.

\section{Changes in the soil parameters}

Table 5. Changes in measured soil parameters as affected by the two crop management systems during the two seasons

\begin{tabular}{lllllll}
\hline Soil parameter & \multicolumn{3}{c}{ Beginning of experiment } & \multicolumn{3}{c}{ End of experiment } \\
\cline { 2 - 7 } & Season 1 & Season 2 & \multicolumn{2}{c}{ Season 1 } & \multicolumn{2}{c}{ Season 2 } \\
& & & \multicolumn{1}{c}{$\mathbf{T}_{1}$} & \multicolumn{1}{c}{$\mathbf{T}_{2}$} & $\mathbf{T}_{1}$ & $\mathbf{T}_{2}$ \\
\hline pH & $7.57 \pm 0.05$ & $6.95 \pm 0.12$ & $7.78 \pm 0.05(2.8)$ & $7.79 \pm 0.04(2.9)$ & $7.00 \pm 0.11(0.7)$ & $7.15 \pm 0.13(2.9)$ \\
Electrical conductivity $(\boldsymbol{\mu S})$ & $109 \pm 23$ & $145 \pm 46$ & $170 \pm 18(56)$ & $168 \pm 16(54)$ & $168 \pm 13(15.9)$ & $185 \pm 13.5(27.6)$ \\
Soil organic matter (\%) & $1.45 \pm 0.07$ & $1.48 \pm 0.11$ & $1.32 \pm 0.1(-18.9)$ & $1.28 \pm 0.12(-11.7)$ & $1.55 \pm 0.13(4.7)$ & $1.46 \pm 0.08(-1.4)$ \\
Total Nitrogen (mg kg ${ }^{-1}$ soil) & $840 \pm 104$ & $1735 \pm 103$ & $1118 \pm 70(33.1)$ & $1040 \pm 59(23.8)$ & $1612 \pm 41(-7.1)$ & $1488 \pm 56(-14.2)$ \\
Available Phosphorous (mg kg ${ }^{-1}$ soil) & $42.6 \pm 5$ & $50.1 \pm 7.8$ & $115 \pm 18(170)$ & $77.6 \pm 11(82.2)$ & $46.6 \pm 2(-6.9)$ & $39.1 \pm 4.7(-21.9)$ \\
Potassium (mg kg ${ }^{-1}$ soil) & $140 \pm 7$ & $158.5 \pm 10.5$ & $204 \pm 6(45.7)$ & $179 \pm 15(27.9)$ & $176 \pm 20(10.8)$ & $166 \pm 26(4.7)$ \\
\hline
\end{tabular}

Note: Mean values of seven farmer fields given with the associated standard errors; Percentage change of a particular parameter in relation to its initial value is given in the parentheses

The changes in the measured soil parameters between two crop management systems were not significant $(p=0.05)$ at the end of both seasons. This indicates that the adaptation package did not cause any detrimental effects on soil properties at the end of each season (Table 5). In contrast, as demonstrated by Chathurika et al. (2014) site-specific fertilizer management helped to correct nutrient deficiencies and avoid excess application thereby minimizing environmental pollution.

\section{The cost-benefit analysis}

Table 6. The approximate cost of operations specifically involved in the two crop management systems in Sri Lankan rupees (LKR)

\begin{tabular}{lll}
\hline Cost component & \multicolumn{1}{c}{$\begin{array}{c}\text { Adaptation package } \\
\left(\mathbf{R s ~ h a}^{-1}\right)\end{array}$} & \multicolumn{1}{c}{$\begin{array}{c}\text { Existing practice } \\
\left(\mathbf{R s ~ h a}^{-1}\right)\end{array}$} \\
\hline Fertilizer application & 24930.00 & 37280.00 \\
Agro-chemicals & NA & 68230.00 \\
IPM materials & 35145.00 & NA \\
Labour for: & & \\
Spraying & 18000.00 & 45000.00 \\
Mulching & 25000.00 & NA \\
Bleach powder application & 10000.00 & NA \\
Hanging sticky traps & 10000.00 & NA \\
Boarder polythene establishment & 10000.00 & NA \\
\hline Total cost & 133075.00 & 150510.00 \\
\hline Cost difference & {$[\mathbf{1 3 3 0 7 5 . 0 0 - 1 5 0 5 1 0 . 0 0 ] = 1 7 4 3 5 . 0 0 ~ p e r ~ h a ~}$}
\end{tabular}


The adaptation package was cheaper by about 17435.00 LKR per hectare than the existing practice, which involved heavy applications of pesticides and fungicides (Table 6). During the first season, the yield under the adaptation package was slightly lower by $0.6 \mathrm{t} \mathrm{ha}^{-1}$, which however, was not statistically-significant at $p=0.05$ (Table 4). At an average farm gate price of 75.00 LKR per $\mathrm{kg}$, a farmer adopting the adaptation package would have incurred a loss of 27,565.00 LKR ha ${ }^{-1}$ during the first season. This was because the monetary loss due to lower yield (i.e. 45,000 LKR ha ${ }^{-1}$ ) was greater than the cost-saving (17435.00 LKR ha ${ }^{-1}$ ) that the farmer enjoyed under the adaptation package. However, the yield of the adaptation package was greater by $4.24 \mathrm{t} \mathrm{ha}^{-1}$ in the second season (Table 4), which was statisticallysignificant $(p<0.05)$, giving a monetary benefit of $318,000.00 \mathrm{LKR} \mathrm{ha}^{-1}$. Thus, farmers enjoyed an overall monetary benefit of $335,435.00 \mathrm{LKR} \mathrm{ha}^{-1}$ (with the cost saving of 17435.00 LKR ha ${ }^{-1}$ ) in the second season under the adaptation package over the existing practice.

\section{Field environmental impact quotient (FEIQ)}

The FEIQ developed at the Cornell University, USA can be used to estimate the toxicological impacts of a number of commonly used pesticides (Kovach et al., 1992). It takes in to account three components of the impacts, namely impacts to the workers, consumers and the environment (i.e. ecology).

Table 7. Calculated Field environmental impact quotient (FEIQ) and its partial components of the two crop management systems

\begin{tabular}{|c|c|c|c|c|}
\hline \multirow[b]{2}{*}{ Crop Management System } & \multicolumn{3}{|c|}{ Impact components* } & \multirow[b]{2}{*}{ FEIQ* } \\
\hline & Consumer & Worker & Ecology & \\
\hline Adaptation Package & 6.2 & 68.6 & 40.2 & 38.3 \\
\hline Existing Practice & 124.3 & 325.2 & 1063 & 505 \\
\hline
\end{tabular}

*Greater numeric values indicate greater toxicological impacts on the environment and its components

A greater value for FEIQ indicates a greater toxicological impact on the environment. As shown in Table 7, the FEIQ of the existing practice was 13.2 folds greater than that of the adaptation package. This clearly shows the environmental hazards of intensive use of agrochemicals in the existing system of potato cultivation and also indicates the eco-friendliness of the introduced adaptation package. Therefore, it is notable that even the small and statistically non-significant $(p=0.05)$ monetary loss shown during Season 1 would have been outweighed by the substantially greater environmental benefits of the adaptation package, which are not included in the monetary cost-benefit calculation. These environmental benefits will have long-term positive impacts on the soil and the above-ground environment and these will be translated in to gains in yield as demonstrated during Season 2.

\section{CONCLUSIONS}

The present study demonstrated the promising benefits of the introduced adaptation package in terms of improvement of growth, yield, economy and environmental friendliness of potato cultivation in the Jaffna District of Sri Lanka. The farmers may not achieve the financial benefit under the adaptation package in the first season as they were in the introductory stage 
of adoption, which always takes time. However, the introduced package achieved performances, which were equal to the existing practice even in the first season. Moreover, it has significantly $(p=0.05)$ enhanced the production performances in the second season. Thus, this adaptation package could be recommended for adoption by the farmers to improve the yield of potato while promoting lower water and agro-chemical use thereby having increased resilience to climate change resulting in improved environmental sustainability especially in the dry regions where potato is cultivated.

\section{ACKNOWLEDGEMENT}

The authors wish to thank HETC/QIG/W3/PGIA Grant for the financial support and to the Department of Agriculture officers and farmers in the Jaffna District who participated and contributed to this adaptive research.

\section{REFERENCES}

Abawi, G.S. and Widmer, T.L. (2000). Impact of soil health management practices on soil borne pathogens, nematodes and root diseases of vegetable crops. Applied Soil Ecology. 15(1), 37 - 47.

Abhayapala, K.M.R.D., De Costa, W.A.J.M., Fonseka, R.M., Prasannath, K., De Costa, D.M., Suriyagoda, L.D.B., Abeytilakarathna, P.D. and Nugaliyadda, M.M. (2014). Response of potato to increasing growing season temperature under different soil management and crop protection regimes in the up-country of Sri Lanka. Tropical Agricultural Research. 25(4), 555 - 569.

Antwi-Agyei, P., Dougill, A.J. and Stringer, L.C. (2015). Barriers to climate change adaptation: evidence from northeast Ghana in the context of a systematic literature review. Climate and Development. 7(4), 297 - 309.

Bremner, J.M. (1960). Determination of nitrogen in soil by the Kjeldahl method. The Journal of Agricultural Science. 55(1), 11 - 33.

Chathurika, J.A.S., Indraratne, S.P. and Dandeniya, W.S. (2014) Site specific fertilizer recommendations for maize (Zea mays) grown in reddish brown earth and reddish brown latasolic soils. Tropical Agricultural Research. 25(3), 287 - 297.

De Costa, W.A.J.M. (2008). Climate change in Sri Lanka: myth or reality? Evidence from long-term meteorological data. Journal of National Science Foundation Sri Lanka, 36 Special Issue: $63-88$.

DOA, (2014). AgStat: Pocket Book of Agricultural Statistics. Volume 6, Department of Agriculture, Peradeiya, Sri Lanka.

Gregory, P.J., Johnson, S.N., Newton, A.C. and Ingram, J.S.I. (2009). Integrating pests and pathogens into the climate change/food security debate. Journal of Experimental Botany 60(10), 2827 - 2838. 
Howden, S.M., Soussana, J.F., Tubiello, F.N., Chhetri, N., Dunlop, M. and Meinke, H. (2007). Adapting agriculture to climate change. Proceedings of the National Academy of Science (PNAS), USA, 104, 19691 - 19696.

Kovach, J., Petzoldt, C., Degni, J. and Tette, J. (1992). A method to measure the environmental impact of pesticides. New York's Food and Life Sciences Bulletin. 139, 1 - 8.

Kumar, S.D. and Lal, B.R. (2012). Effect of mulching on crop production under rainfed condition - A Review. International Journal of Research in Chemistry and Environment. 2(2), $8-20$.

Lobell, D.B. (2014). Climate change adaptation in crop production: Beware of illusions. Global Food Security. 3(2), 72 - 76.

Malaviarachchi, M.A.P.W.K., De Costa, W.A.J.M., Fonseka, R.M., Kumara, J.B.D.A.P., Abhayapala, K.M.R.D. and Suriyagoda, L.D.B. (2014). Response of maize to a temperature gradient representing long-term climate change under different soil management systems. Tropical Agricultural Research. 25(3), 327 - 344.

Meinke, H., Howden, S.M., Struik, P.C., Nelson, R., Rodriguez, D. and Chapman, S.C. (2009). Adaptation science for agriculture and natural resource management-urgency and theoretical basis. Current opinion in Environmental Sustainability. 1, 69 - 76.

Nelson, D.W. and Sommer L.E. (1996). Total organic carbon and organic matter. In: Sparks, D.L. (Ed.) Method of Soil Analysis, Part 3, Chemical Methods: pp. 36-404. American Society of Agronomy, soil science society of America, Madison, Wisconsin, USA.

Portch, S. and Hunter, A. (2002). A systematic approach to soil fertility evaluation and improvement. (Special publication No. 5) Canpotex limited, Hong Kong.

Prasannath, K., Dharmadasa, K.N.P., De Costa, D.M. and Hemachandra, K.S. (2014). Variations of incidence and types of virus diseases and insect vector populations of tomato grown in different agro-ecological regions under two crop management systems. Tropical Agricultural Research. 25(3), 376 - 395.

Punyawardena, B.V.R., Dissanayaka, T. and Mallawatantri, A. (2013). Spatial variation of climate change induced vulnerability in Sri Lanka. Department of Agriculture, Sri Lanka.

Rosenzweig, C., Karoly, D., Vicarelli, M., Neofotis,P., Wu, Q., Casassa, G., Menzel, A., Root, T.L., Estrella, N., Seguin, B. et al. (2008). Attributing physical and biological impacts to anthropogenic climate change. Nature. $453,353-358$.

Schumann, G.L. and Arcy, C.J.D. (2000). Late blight of potato and tomato. The Plant Health Instructor. DOI: 10.1094/PHI-I-2000 - 0724 - 01

Sood, A., Manthrithilake, H., Siddiqui, S., Rajah, A. and Pathmarajah, S. (2015). Managing shallow aquifers in the dry zone of Sri Lanka. Environmental Monitoring and Assessment. 187,400 .

St. Clair, S.B. and Lynch, J.P. (2010). The opening of Pandora's box: Climate change impacts on soil fertility and crop nutrition in developing countries. Plant and Soil. 335, 101 115. 
Steel, R.G D., Torrie, J.H. and Dickey, D.A. (1997). Principles and Procedures of Statistics: A Biometrical Approach. $3^{\text {rd }}$ Ed. Mc Graw Hill Book Co. Inc. New York.

Vithanage, M., Thushyanthi, M., Pathmarajah, S., Sutharsiny, A. and Manthrithilake, H (2014). Assesment of nitrate-N contamination in the Chunnakam aquifer system, Jaffna Peninsula, Sri Lanka. Springerplus. 3, 271. 